\section{A possible case of posttraumatic obsessive-compulsive disorder}

\section{Um possivel caso de transtorno obsessivo- compulsivo pós-traumático}

Dear Editor,

Exposure to traumatic experiences (crimes, violence, accidents, natural disasters), involving death or death threat, severe wounds or risk to physical integrity, leading to intense fear, helplessness or horror, are important factors in the etiology of several mental disorders. Many recent studies have focused on biological factors of obsessive-compulsive disorder (OCD) etiology, but few have addressed environmental factors, particularly traumatic events.

Herein we report the case of a patient with no psychiatric history who developed posttraumatic stress disorder (PTSD), depression and OCD after a serious work accident.

Five years ago, O.M.V., a 35 year-old married man, refrigeration machine operator, was exposed to a severe explosion involving an ammonia anhydrous compressor. He experienced moments of horror while helping to save a co-worker and suffered second degree burns over $30 \%$ of his body, demanding prolonged treatment. PTSD symptoms began shortly afterwards: intense anxiety, fear, intrusive memories, flashbacks, insomnia, nightmares, hypervigilance, and avoidance behaviors. He also presented depressive mood, lack of pleasure and interest, social isolation, weight gain and diminished libido. He later developed ego-dystonic thoughts unrelated to the initial trauma, mainly fear of other catastrophic events and harming other people. Fearing involuntary aggressive impulses, he stopped using knives and other dangerous objects and quit driving. He presented checking rituals, not only concerning gas cylinders, but also doors and windows and his wife's breathing during sleep. He performed repeated hand-washing, showering and teeth-brushing, believing he had bad odors and feared being contaminated by fatal illnesses, such as AIDS, while refusing to shake other people's hands to avoid contaminating them. He developed counting rituals without associated obsessions and a fear of heights. He scored 30 on the initial OC symptom severity (Y-BOCS, max.: 40) assessment and 24 on the Beck Depression Inventory (moderate severity). He presented some panic attacks in trauma-related situations or when his OC symptoms worsened. The interference of symptoms in all aspects of his life was dramatic. In 2006 he tried to return to work, but failed, attempting suicide by taking medicines, receiving extended medical leave. Adequately dosed medications provided no response, including fluoxetine, sertraline, citalopram, bupropion, paroxetine and fluvoxamine. He is currently taking venlafaxine $150 \mathrm{mg} /$ day and initiating cognitive-behavioral psychotherapy, though his symptoms are still incapacitating.

Pitman reported that a Vietnam soldier developed PTSD and OCD after the war and cited Janet, who described the case of a woman who developed OCD after seeing her daughter's body burnt in a fire. ${ }^{1}$ Other authors have reported cases in which clear connections occurred between traumatic experiences and OCD onset. ${ }^{2-4}$

OCD symptoms content is usually related to the trauma, and an overlap of PTSD and OCD symptoms occurs for some time..$^{1-3}$ Since the psychopathology of PTSD-related intrusive thoughts and depressive ruminations is similar to obsessions, differential diagnosis between PTSD, depression and OCD should be considered.

Overestimation of risks and the need for absolute certainty, security and control are core OCD characteristics, therefore, it is understandable that exposure to really dangerous and frightening situations may favor OCD development in predisposed persons.

Further studies regarding the role of traumatic experiences in OCD etiology are required, since trauma-related OCD may constitute a particular subtype, with treatment implications. ${ }^{5,6}$

\section{Edson Capone de Moraes Jr., Ricardo Cezar Torresan, Erica Vasques Trench, Albina Rodrigues Torres Botucatu Medical School, Universidade Estadual} de São Paulo (Unesp), Botucatu (SP), Brazil

\section{References}

1. Pitman RK. Posttraumatic obsessive-compulsive disorder: a case study. Compr Psychiatry. 1993;34(2):102-7

2. de Silva P, Marks M. The role of traumatic experiences in the genesis of obsessive-compulsive disorder. Behav Res Ther. 1999;37(10): 941-51.

3. Gershuny BS, Baer L, Radomsky AS, Wilson KA, Jenike MA. Connections among symptoms of obsessive-compulsive disorder and posttraumatic stress disorder: a case series. Behav Res Ther. 2003;41(9):1029-41.

4. Sasson Y, Dekel S, Nacasch N, Chopra M, Zinger Y, Amital D, Zohar J. Posttraumatic obsessive-compulsive disorder: a case series. Psychiatry Res. 2005;135(2):145-52.

5. de Mathis MA, Diniz JB, do Rosário MC, Torres AR, Hoexter M, Hasler G, Miguel EC. What is the optimal way to subdivide obsessive-compulsive disorder? CNS Spectr. 2006;11(10):762-8, 771-4, 776-9.

6. Ferrão YA, Diniz JB, Lopes AC, Shavitt RG, Greenberg B, Miguel EC. Resistência e refratariedade no transtorno obsessivo-compulsivo. Rev Bras Psiquiatr. 2007;29(Supl 2):S66-76.

\title{
Disclosures
}

\begin{tabular}{|c|c|c|c|c|c|c|c|}
\hline $\begin{array}{l}\text { Writting group } \\
\text { member }\end{array}$ & Employment & $\begin{array}{l}\text { Research } \\
\text { grant }^{1}\end{array}$ & $\begin{array}{c}\text { Other research grant or } \\
\text { medical continuous education }\end{array}$ & $\begin{array}{l}\text { Spekear's } \\
\text { honoraria }\end{array}$ & $\begin{array}{l}\text { Ownership } \\
\text { interest }\end{array}$ & $\begin{array}{c}\text { Consultant/ } \\
\text { Advisory board }\end{array}$ & Other $^{3}$ \\
\hline $\begin{array}{l}\text { Edson Capone de } \\
\text { Moraes Jr. }\end{array}$ & FMB-UNESP & -- & - & - & - & - & - \\
\hline $\begin{array}{l}\text { Ricardo Cezar } \\
\text { Torresan }\end{array}$ & FMB-UNESP & - & - & - & -- & - & - \\
\hline $\begin{array}{l}\text { Erica Vasques } \\
\text { Trench }\end{array}$ & FMB-UNESP & - & - & - & - & - & - \\
\hline $\begin{array}{l}\text { Albina Rodrigues } \\
\text { Torres }\end{array}$ & FMB-UNESP & - & - & - & - & -- & - \\
\hline
\end{tabular}

* Modest

** Significant

** Significant. Amounts given to the author's institution or to a colleague for research in which the author has participation, not directly to the author

Note: FMB-UNESP = Faculdade de Medicina de Botucatu, Universidade Estadual de São Paulo.

For more information, see Instructions to Authors. 